\title{
DEVELOPMENT OF A SOCIAL BUSINESS AS A SOCIAL INNOVATION: THE CASE OF LITHUANIA
}

\author{
Daiva ANDRIUŠAITIENĖ(iD ${ }^{1 *}$, Gerda VIŽINYTE் (D) ${ }^{2}$ \\ ${ }^{I}$ Department of Economic Engineering, Faculty of Business Management, Vilnius Gediminas Technical Unversity, \\ Sauletekio al. 11, 10223, Vilnius, Lithuania \\ ${ }^{2}$ Company Aljansas Aibe, Commerce Department, L. Zamenhofo g. 5, 06332, Vilnius, Lithuania \\ ${ }^{*}$ E-mail: daiva.andriusaitiene@vgtu.lt
}

\begin{abstract}
Purpose of this article is to assess the first steps of development of social business in Lithuania.
Research methodology - systematic analysis of the peculiarities of social business in the scientific literature; identification of the main social problems and possibilities for social business based on results of semi-structured interviews, expert assessment, data grouping and interpretation.

Findings - social business development is slow compared to its need. The creation of a legal framework, validating a flexible model of social business and wider social advertising campaign can serve as catalysts for the breakthrough to pave the way for social business development.

Research limitations - the main limitation - lack of official social business statistics. Another - factor of subjectivity, which could affect the results of the research, revealing only the main tendencies and problems. In the planning of further research, it is possible to seek greater objectivity of the evaluation by improving the survey questionnaire, to evaluate the social and economic efficiency of social business by the cost-benefit analysis method.
\end{abstract}

Practical implications - the obtained results are useful for social and economic policy makers.

Originality/Value - the study contributes to scientific literature by sufficient understanding of practical problems of social business development and fills the gap in research of possibilities of social business development.

Keywords: social business, economy, poverty, unemployment, social innovation.

JEL Classification: O11, O35, P30.

Conference topic: Contemporary Issues in Economics Engineering.

\section{Introduction}

Business is the basis of the economy serving to satisfy the needs of society. It usually performs successfully in coping with economic problems. However, activities that do not guarantee profit-earning opportunities typically fall outside the scope of business interests. Social, environmental and other problems in the areas important for the welfare of civilized society are the responsibility of the State.

However, society's social responsibility is also growing in line with the changing global economy and continuously rising welfare standards, and the increasing understanding that the growing wealth gap which is the key determinant for social differentiation is an important welfare risk factor. Socially responsible behavior is viewed as economically beneficial from a macro-level perspective, it being understood that welfare itself is possible only in societies that are relatively homogeneous in welfare terms.

The development trends in social and economic considerations are changing the behavior of all economic entities: enterprises are not only increasingly declaring their social responsibility but also behaving in a socially responsible manner; public authorities develop relevant programmes; responsible and creative modern society creates and develops social businesses that are considered to be social innovation.

Social business as innovation in foreign countries are developing rapidly, and they are supported in the European Union countries. In Lithuania, there is a lack of advertising about what innovation is a social business, what its possibilities are, and about the best examples of good practices. Increased dissemination of information and a favorable legal environment could encourage the development of this social innovation and become a significant response to social problems. 


\section{Research methodology}

The purpose of this article is to assess the development problems and possibilities of social business in Lithuania. The tasks of the article are to characterize the peculiarities of social business, to identify the main social problems as possible areas of social business activities, to present the results of the expert assessment of the status and prospects of the development of social business in Lithuania.

Methods of research: systematic analysis of scientific literature, semi-structured interview, expert assessment, data grouping and interpretation.

The expert assessment questionnaire was based on an analysis of social business theoretical issues and a semistructured in-depth interview with 2 social business experts. The questionnaire consists of 7 closed questions with the provided answers, 3 questions for experts evaluation, 1 question is in open form. On closed issues, the aim was to find out the peculiarities and importance of the activity of the expert company, and openly - the opinion of the expert on the possibilities, problems and perspectives of applying the social business model in Lithuania. The aim of the open questions was to obtain additional information and insights on aspects that might not be included in the survey questionnaire. The survey was conducted in December 2017. All representatives of social entrepreneurs who were involved in social business projects were invited to carry out the expert assessment, but only 7 respondents answered the questions. The compatibility of the opinions of the experts who participated in the survey was confirmed by the calculated concordance coefficient. The main limitation of the research is the lack of official social business statistics. Another factor of subjectivity, which could affect the results of the research, revealing only the main tendencies and problems. In the planning of further research, it is possible to seek greater objectivity of the evaluation by improving the survey questionnaire.

\section{The concept of social business}

The European Union attaches great importance to reducing socio-economic exclusion, unemployment, equal opportunities issues and other social problems. In addition to national authorities, all other organizations whose primary goal is to meet human needs rather than to seek financial benefits, can contribute to the solution of these problems; such organizations may make a profit, but this is not the main purpose of their activities; all funds are used for social mission (Campos, Spear, \& Frobel, 2012; Yunus, 2017). These are enterprises that fill the gap in missing public services, i.e. social business.

Talk of social business in Europe began already in 1990 in Italy. Although it is only a relatively new phenomenon, there is no universally approved definition for it. Lithuanian and foreign experts and institutions provide different definitions (Table 1).

However, the key emphasis in all of the definitions is on mission: "the primary mission is creating social value by providing solutions to social problems" (Santos, 2012); business organisations initiate or contribute to creating positive changes through innovative business principles (Idowu, Schmidpeter, \& Fifka, 2015); etc.

Social business is dedicated to reduce social problems and create social value for the members of society. As social value may be inter alia related to economic benefits, the emphasis is to be placed not on the social-economic dividing line, but on beneficiaries (Idowu et al., 2015; Kramer, 2005; Lisetchi \& Brancu, 2013; Melnikas, Jakubavičius, Leichteris, \& Stumbrytè, 2017; Phills, Deiglmeier, \& Miller, 2008; Stropute \& Kairytè, 2016a).

A distinction can be made between two major cultures of social business: Anglo-American and European. The spectre of Anglo-American definitions of social business is rather broad, ranging from non-profit enterprises pursuing social missions up to those with social innovations as their central axis.

European traditions rely on three aspects characterizing social business: social, entrepreneurial and governance.

Table 1. Definitions of social business (source: compiled by authors)

\begin{tabular}{|l|l|}
\hline \multicolumn{1}{|c|}{ Source } & \multicolumn{1}{c|}{ Definition } \\
\hline socialinisverslas.lt & $\begin{array}{l}\text { Organizations the mission of which is to find creative, entrepreneurial solutions to major } \\
\text { society's problems such as poverty, lack of education opportunities, unemployment, health } \\
\text { problems and other problems facing societies or small communities }\end{array}$ \\
\hline $\begin{array}{l}\text { Order of the Minister for the } \\
\begin{array}{l}\text { Economy on the Approval of } \\
\text { the Concept of Social Entrepre- } \\
\text { neurship (2015) }\end{array}\end{array}$ & $\begin{array}{l}\text { It is a business model whereby profit-seeking is related to social objectives and priorities } \\
\text { through the use of market mechanisms; it is based on socially responsible business and } \\
\text { public-private partnership provisions, and application of social innovations }\end{array}$ \\
\hline $\begin{array}{l}\text { Nacionalinis socialinės inte- } \\
\text { gracijos institutas (National } \\
\text { Institute for Social Integration) }\end{array}$ & $\begin{array}{l}\text { It is an opportunity for people willing to combine good deeds with the sources of living. It } \\
\text { is a way for tackling problems following a targeted and sustainable line }\end{array}$ \\
\hline
\end{tabular}


End of Table 1

\begin{tabular}{|l|l|}
\hline \multicolumn{1}{|c|}{ Source } & \multicolumn{1}{c|}{ Definition } \\
\hline $\begin{array}{l}\text { Schwab Foundation for Social } \\
\text { Entrepreneurship }\end{array}$ & $\begin{array}{l}\text { It is an organization pursuing stable, measurable, systematic social changes and using new } \\
\text { inventions, technologies, strategies and approaches to achieve this }\end{array}$ \\
\hline $\begin{array}{l}\text { Social Enterprise Virtue } \\
\text { Ventures }\end{array}$ & $\begin{array}{l}\text { It is an enterprise created as a tool to solve social problems through private-sector prac- } \\
\text { tices }\end{array}$ \\
\hline Yunus & $\begin{array}{l}\text { Business with a clearly defined social mission, which is measured by social impacts rather } \\
\text { than generated profits. Part of profits goes to investors until return of their initial invest- } \\
\text { ments and then 100\% of profits are reinvested back into a solution of the set social prob- } \\
\text { lems }\end{array}$ \\
\hline $\begin{array}{l}\text { Department of Trade and } \\
\text { Industry (2002) (UK) }\end{array}$ & $\begin{array}{l}\text { Social business are non-profit organizations providing goods or services directly aimed at } \\
\text { benefiting the community. They generally rely on a collective responsibility assumed by } \\
\text { various types of stakeholders, have a high degree of autonomy and bear economic risks re- } \\
\text { lated to their activity }\end{array}$ \\
\hline $\begin{array}{l}\text { Dietrich, Znotka, and Guthor } \\
\text { (2015) }\end{array}$ & $\begin{array}{l}\text { Business with specifically defined social aims where profits are not distributed among the } \\
\text { shareholders but are reinvested in the community or the same business to increase contri- } \\
\text { butions to the implementation of the set social goals }\end{array}$ \\
\hline
\end{tabular}

The social aspect defines the primary social purpose which helps distinguish social business from the traditional profit-making business entities. Social dimension indicators are: description of an organisation's activities to ensure the social benefit; identification of target groups and beneficiaries of the organization's activities.

The entrepreneurial aspect requires ongoing engagement in the economic activity. This distinguishes social business from traditional non-governmental organizations and other social economy entities with a social purpose but no regular economic activity. The indicators of this aspect are: market revenue share (the percentage of income from market sources, taxes, including annual membership fees; rental income; public procurement); paid labor force (what part of the whole organization's workforce are salaried employees).

The governance aspect focuses on mechanisms to ensure the achievement of social goals. It even more strictly separates social entrepreneurship from traditional businesses and non-governmental organizations. In this case, the main criteria are as follows:

- Limits on profit distribution: whether profits may be distributed or not. If profits may be distributed, what limits are set;

- The asset lock mechanism: ensures that assets of the organization remain for social purposes, even if the organization discontinues its activities;

- Autonomy: whether the organization is independent (fully or partially) from public-sector organizations and other profit and non-profit organizations;

- Inclusive management provides for balanced participation and representation of all the interested parties (e.g., salaried employees, volunteers, clients, users, beneficiaries, investors), and the democratic principle (one member-one vote);

- Transparency: whether social business has a system for measuring and communicating social impacts to the interested parties (Stroputè \& Kairytè, 2016b).

Thus, it is quite difficult to provide an unambiguous definition of social business. By distinguishing the AngloAmerican and European trends of social business and their key indicators, it is noteworthy that features and certain aspects are emphasized more. Also, certain areas are highlighted that distinguish social business from the traditional business model. One of the most important and greatest differences is the social mission.

\subsection{Social business models}

It is suggested that social business would be classified based on the level of integration of social business to main activities (Alter, 2007):

Pure social business model. This model is distinguished by full integration where business is used as a tool to solve social problems and profits are not distributed among the shareholders. All profits go for tackling social problems. This concept was broadly analyzed by Professor Muhammad Yunus who was awarded a Nobel Prize for his practical works in this field. He defines a social enterprise as a business with a clearly defined social mission, which is measured by social impacts rather than by generated profits. According to this social business model, part of profits goes to investors until the return of their initial investments and then all of the profits are reinvested back into the solution of the set social problems. The following social business principles are identified (Yunus, 2007): 1. The mission of the social business is to solve specific social problems in society (through social innovations or application of successful practices). 2. Social business is financially sustainable and has a viable business model. 3. Social business does not pay dividends to investors. Capital maximization is not the purpose of social business. 4. Profits are allocated to solve social problems or reinvested back in the development of social business. 5. Social business is environment-consistent. 
6. Employees are paid on or above the market level and enjoy above-average working conditions. 7. Social entrepreneurs believe in what they do and therefore easier achieve their potential.

Social business should be built in the same manner as traditional businesses: it requires assessment of all risks, development of a business plan, measuring and assessment of expectations. As in case of any other business, social business requires initial capital which can be received from local authorities support, funded from target foundations or lent by private or institutional lenders. Depending on investors' needs, initial investments may be returned to them, but no interest is payable (Yunus, 2010).

To sum up: social business based on the principles of the pure model has characteristics typical to traditional business and non-profit organizations. Activities should be profitable so that to ensure continuation while concurrently seeking maximization of social value (Alter, 2007).

Hybrid social business model. The essence of the model (Nicholls, 2008): social problem solving while seeking profits for the enterprise's shareholders. The purpose of the hybrid social business model is to optimize the social value through the use of a variety of business strategies and service systems, while gaining financial benefits. The hybrid social business model is still under development, so it is important to emphasize that there is currently no favorable external environment and legal framework necessary to accelerate the development of this social business model.

It is important to distinguish social business models according to their purpose or benefit: the hybrid social business model is an intermediate option between the pure social business model (Brooks, 2008; Yunus, 2007). The pure social business model is identified with philanthropy for reasons that are understood as good intentions. This model uses the economic benefits it generates only to create additional social value, whereas the motives of the hybrid business model are mixed, meaning that it pursues a social impact, but also seeks financial benefits for the owners or shareholders. Therefore, the hybrid business model is often criticized for using social responsibility only as a marketing tool.

According to Prof. Muhammad Yunus, a hybrid social business may qualify for this status if at least $51 \%$ of the economic benefits generated go for creating social value, and only $49 \%$ are for personal financial well-being. However, even in this case it is impossible to avoid situations where social purposes require sacrifices of financial goals and vice versa. Therefore, only enterprises that allocate more than half of their profits for social purposes are in a position to avoid drifting from their initial social mission (Yunus, 2007).

Alter offers a method for classifying social business into three categories based on the level of integration between social programmes and business activities (Figure 1): embedded social business, integrated social business and external social business.

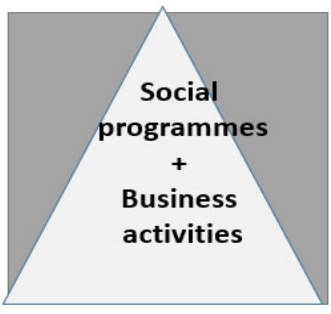

Embedded social business

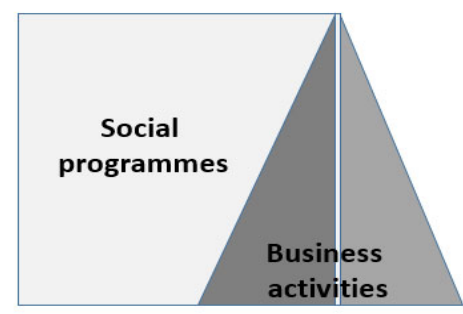

Integrated social business

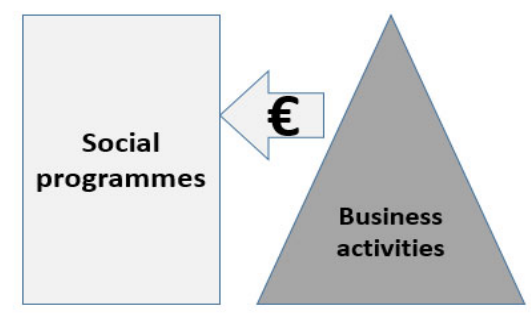

External social business

Figure 1. Social business classification based on the level of integration between social programmes and business activities (source: Alter, 2007)

In accordance with the classification, embedded social business are usually mission-centric. The relationship between business activities and social programmes is comprehensive: financial and social benefits are achieved simultaneously. Due to their mission focus, enterprises are structured as non-profit organizations, but may also be registered as for-profits depending on the legal environment. Examples of such business may include social business established to employ disadvantaged people. In this case, social programmes and business activities coincide and business is the basis of the social mission.

Integrated social business is a mission-related social business. In such social business models, social programmes overlap with business activities, mainly sharing costs and assets. Enterprises and organizations create a social business as a funding mechanism to support non-profit operations and activities related to the social mission. An integrated social enterprise may be structured as a department within a non-profit organization or as a separate entity. Integrated social business expands the organization's social mission by providing paid social services and introducing related unpaid social services in parallel.

External social business is unrelated to social mission, as their social programmes are distinct from business activities. Such social business is established by non-profit organizations in order to ensure funding for their social 
services or operating costs. Legal status depends on the regulatory environment in which the external social enterprise operates or on its access to funding sources (i.e. loans or equity investments). The relationship between business activities and social programmes is supportive, providing unrestricted funding to the parent organization (Haber, 2016; Jakubavičius, Leichteris, \& Stumbrytè, 2016).

In summary, the classification of social business based on the level of integration between social programmes and business activities enables identification of social values and precisely correlates with commercial business activities. It also provides an understanding of the balanced use of resources and assets, and what strategies are used to generate income and benefit in order to create social values.

\section{The hottest areas of social problems in Lithuania}

Like other EU countries, Lithuania is dealing with social issues relevant to the country. Some of them are typical (Yunus, 2017), some determined by historical periods, culture, conditions and other circumstances. Others are more specific to one or another country. Economic and financial capacities to deal with the problems vary, and so do the programmes, measures and targeted priority groups, as well as the level of commitment of public-sector institutions to increase the welfare of these groups.

Who belongs to social risk groups in Lithuania? Most often, these are people who, for one reason or another, are separated from different areas of society, usually belonging to disadvantaged or socially vulnerable groups.

Traditional defining the groups of factors that determine the social exclusion of individuals: social-economic, legal-political, and cultural-psychological. In each case, the main causes of social exclusion are different, but it is possible to identify the most common ones. Criminal history, unemployment, affiliation to ethnic minorities, no habitual residence and combinations of similar problems are the main reasons for leaving a person outside social life. But not only these. Having no telephone, bank account or other modern attributes can also be the cause of social exclusion. All this, put together with problems of the legal-political system (human rights, internal political situation, the level of corruption in the country, etc.) and cultural-psychological factors (rooted stereotypes hindering harmonious communication of people), creates problematic social groups - marginalized castes. In summary, social exclusions are determined by the groups of economic, social and cultural-psychological factors.

Unemployment and precarious work, addictions and poor public health, educational, cultural, political and legal, and other social problems lead to social exclusion. In the most complicated cases, a particular person or family experiences exclusion almost for all those reasons: single elderly, disabled, poor homeless persons or impoverished disadvantaged families with many children, where parents are unemployed persons with disabilities... However, both single and complex social problems are associated with economic consequences and challenges.

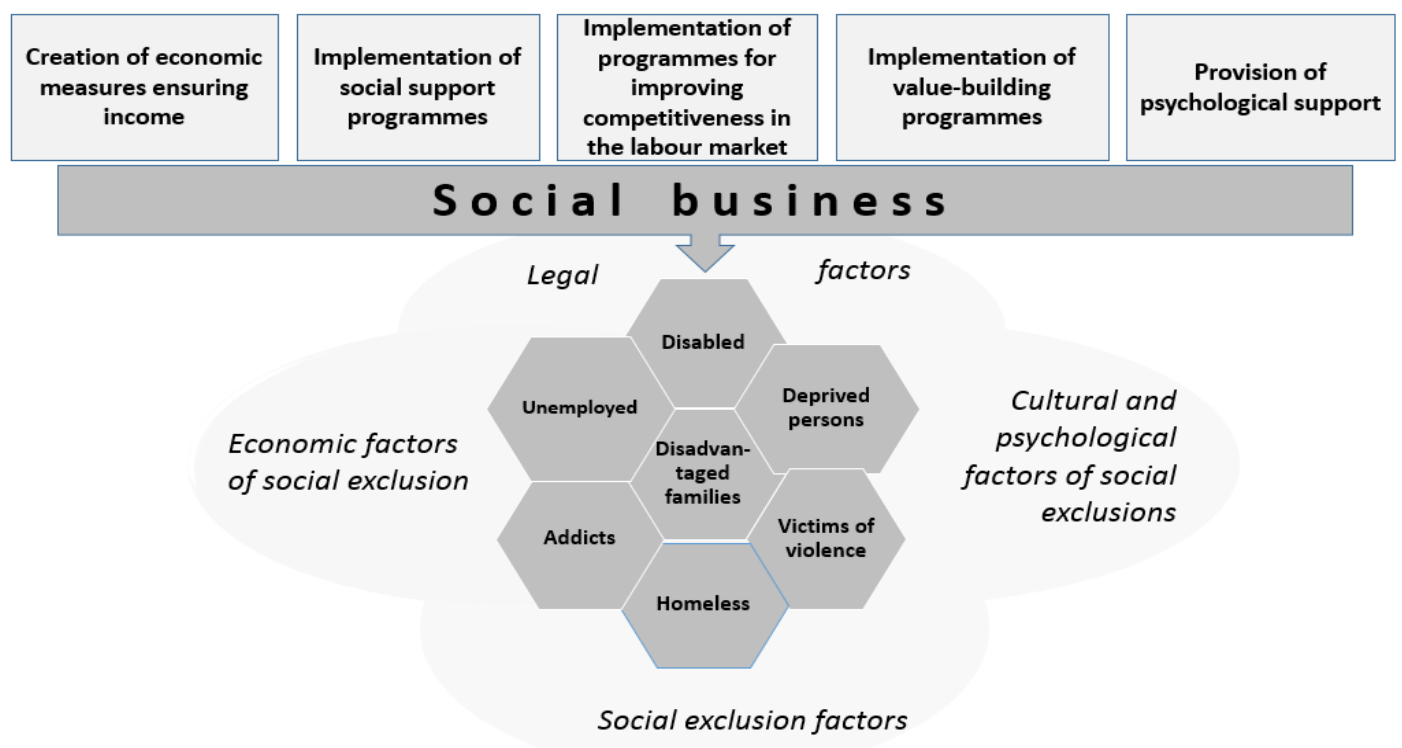

Figure 2. Areas of social business activities and main target groups (source: compiled by authors on the basis of EU support report and SODRA's data)

Who takes care of people facing social and economic problems in Lithuania and how? The Action Plan for Increasing Social Inclusion for 2014-2020 developed by the Ministry of Social Security and Labour (2013) identifies the following vulnerable groups: people suffering from income or other material deprivation, or people otherwise living below, or close to, the relative poverty line; long-term unemployed people and those living in low-intensity households; 
homeless people, i.e. people without their own dwelling who cannot afford it or those who have housing but are unable to keep it; disadvantaged families with children; disabled people; single elderly people.

The main disadvantaged groups are supported by the State Social Insurance System (SODRA): they receive oldage pensions, benefits in case of lost capacity for work, support for widows/widowers and orphans. The social security system provides for home-based help and helps in social care homes; general social services (meals, provision of essential items, personal hygiene articles, transport/transportation). There are day-care centers; assistance is provided to disadvantaged families; relevant institutions take care of children deprived of parental care; elderly and adult persons with disabilities are cared for at care home or sheltered accommodations; there are shelters for the homeless...

However, the social security system does not have sufficient resources for all problematic issues and is not always capable of responding promptly to the problems of one or another exclusion group. In such cases, social business initiatives are welcome. Figure 2 illustrates social exclusion determinants, groups of people, and priority activity areas where social business opportunities are best addressing the needs of society.

The priorities above are important in generating ideas for the concept of social business and decisions towards development.

\section{The first steps of social business in Lithuania}

Social business is a globally recognized social innovation which contributes to addressing social problems in the most diverse areas of life (Dees, Emerson, \& Economy, 2001; Dees, 2007; Murray, Caulier-Grice, \& Mulgan, 2010; Schwab foundation for social entrepreneurship, 2018; Stroh, 2015; Venturi \& Zandonai, 2012). With some delays, social business tries to get a foothold in Lithuania, too. Development is rather slow due to regulatory efforts which are fragmentary in terms of ideas and projects. What is the current situation in Lithuania?

The main documents in this area include: 2004 Law on Social enterprises; 2011 Communication from the Commission - Social Business Initiative; 2015 Approval of the concept of social entrepreneurship in Lithuania; 2015 Social Entrepreneurship Promotion Action Plan for 2015-2017; 2016 The Ministry of the Economy and expert team of the Young Professionals Programme Kurk Lietuvai (Create for Lithuania) developed a Social Business Guide, explaining the benefits of social business; 2016 Amendments to the concept of social entrepreneurship, describing four criteria to be met by social business; 2017 The Ministry of the Economy initiated the drafting of the law on the development of social entrepreneurship. The draft law contains the concept of a social enterprise, the procedure for granting and revoking the status of a social enterprise, forms of state aid applicable to social business and the principles of measuring the positive social impact.

In Lithuania, social business is identified as an important tool to combat poverty, lack of education opportunities, unemployment and growing social exclusion, and the value and prospects of social business are generally recognized. However, social business development in Lithuania is still hampered by unfinished legal documents (in particular, inadequate regulation), relatively low awareness of social business and a development-unfriendly system of financial support. It is only regrettable that decisions awaited by the most courageous enterprises engaged in the relevant activities are being adopted so slowly: it is already 2019, but the law that can boost the development of social business has not yet been adopted.

Examples of social business. The number of social business operating in the country is still not clear. There is no such statistics. Information that could be found in various sources is merely fragmentary, presented as examples of good practice (Social Enterprise Summit, Report, 2017). The information shows that social business initiatives in Lithuania mainly emerge in the areas of non-formal education, social exclusion reduction, reintegration of target groups in the labor market and employment enhancement.

The number of both pure and hybrid social business is small. The most successful initiatives usually include: magazine Žmogus. Déžé (Box Man) - a non-profit social business project aimed at providing job opportunities for people having difficulties in finding work (the sellers of the magazine keep half of the price of the magazines sold); Sékmés mokykla (School of Success) - a non-formal education establishment pursuing the purpose of "helping children in revealing themselves as unique personalities and developing their social competences and essential learning skills to enable their life-long development"; restaurant Mano Guru (My Guru) contributes to solving problems of addicts (who account for $70 \%$ of the restaurant staff (waiters, bartenders, cooks)).

As an embedded social enterprise we can mention Social taxi, service introduced by the National Institute for Social Integration (2017). It is a unique service that helps to organize the travel of people with disabilities to the places of economic and social activities.

As regards integrated social enterprise, UAB PROSAPIA's initiative Visi naujagimiai-lygūs (All Newborns Are Equal) has developed into a social business where one baby's nest is purchased and the second set of basics is given to a disadvantaged mother as a gift.

As an example of external social enterprise we can mention a project by Public Institution Atsakingas verslas aimed at drawing the attention of women to themselves. Trys seserys (The Three Sisters) is implemented in the fashion and business center Herkaus Gallery. The social space for women accommodates a seminar room, a library and a 
charity shop to help keep this project going. The funds raised are used for activities carried out not only in the capital, but also in smaller towns and townships of the country.

Currently, the most common social business models in Lithuania are embedded social business and integrated social business, such as NGOs, support and charity foundations, and social business. In order to boost the development of social business in Lithuania, it is necessary to pay attention to external social business that can be developed by the traditional business sector.

\section{Results of the expert assessment}

There is no official statistical data on social business. Information appearing in various sources is fragmentary. Information published on the Internet by social business representatives about themselves is usually limited to the promotion of the implemented ideas. Therefore, the survey was conducted where 12 social business were asked to reply to the expert questionnaire; however, answers were provided only by 7 social business. Thus, for the purpose of the survey, a group of 7 experts - social business representatives - was formed.

A summary of the results of the expert assessment showed that even $50 \%$ of social business was carried out by public institutions (public legal entities with limited liability, non-profits), private limited liability companies and startups accounted for $20 \%$ each, and the remaining $10 \%$ of social business entities were vocational education and training schools implementing social initiatives. This information cannot be seen as statistically illustrating the structure of social business in terms of the status of legal entities, but it illustrates the possibility for different types of legal entities to integrate social business as part of their activities.

One of the survey questions was about the area of activity of social business entities. In this respect, the most common areas of activity included social services (43\%) (care for children from families at social risk, emotional support for families with problems, support for parents with newborns, accommodation and meals); education and research (29\%) carried out in the public interest (integration into the labour market, (non-)tolerance in society, food and ecology, reconciliation of work and family responsibilities, benefits of memory training at school, and other); local community development (19\%).

The majority of the interviewed social business tackle problems related to poor living conditions (48\%) and poverty $(29 \%)$ (Figure 3).

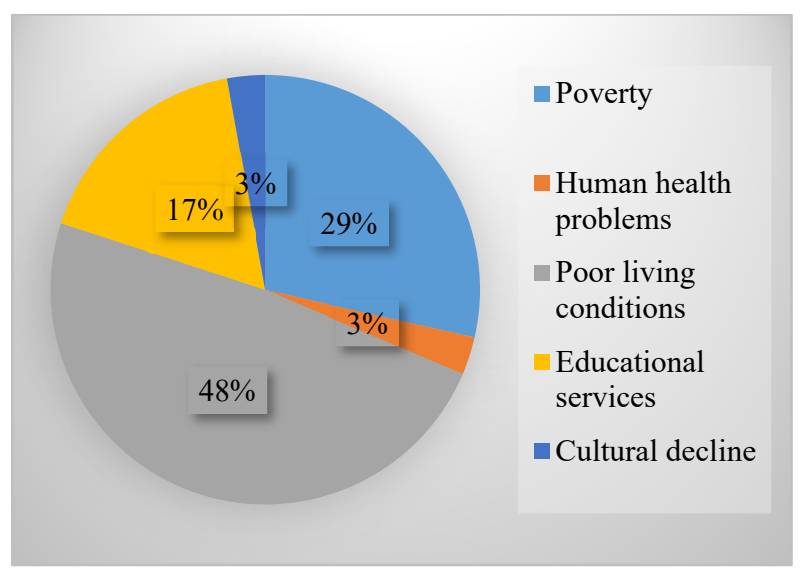

Figure 3. Social problems addressed by social business (source: compiled by authors)

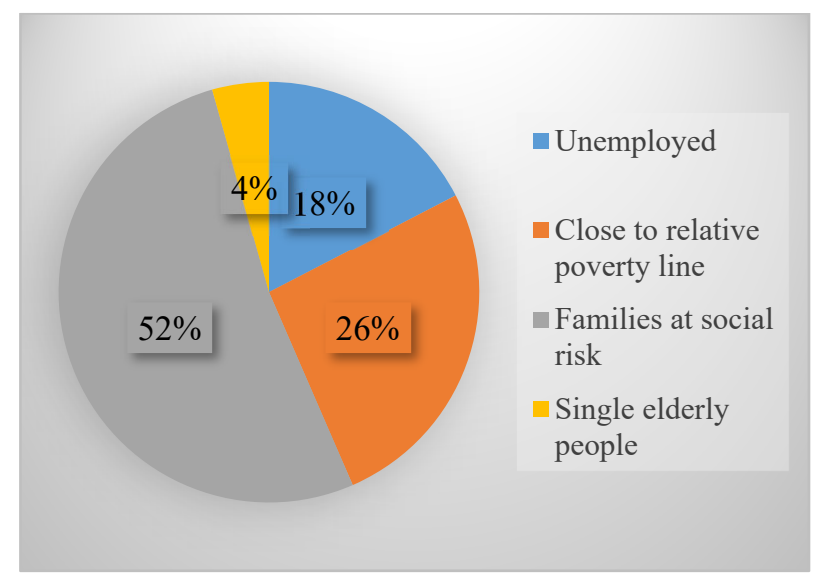

Figure 4. Beneficiaries of services of social business (source: compiled by authors)

The most common areas of activities mentioned by social business are services for single elderly people in order to improve their living conditions, practical help for parents with pre-term babies, and support for pregnant mothers. Educational problems are tackled by teaching social entrepreneurship, leadership, and health - increasing the mobility of people with disabilities. Cultural heritage and customs attract somewhat less attention. In the course of this survey, experts pointed out that the majority of their activities are services for disadvantaged families living in poor conditions (52\%), people living close to the relative poverty line (26\%) and the unemployed (18\%). Support for the elderly account for the least portion of activities carried out by social business (4\% of beneficiaries) (Figure 4).

The interviewed experts, representatives of social business, assessed the factors that determine social problems, which have been classified into six groups of factors: social (crime, no habitual residence, limited access to technologies and higher education, social stigma, discrimination, etc.); economic (unemployment, low pay, business, inflation, high taxes, etc.); legal (problems with human rights in the country, lack of regulations protecting human rights, etc.); political (internal political situation, corruption, etc.); cultural (demographic and cultural changes, ethnic minorities, social classes, etc.); psychological (rooted stereotypes, behavioural norms, values, etc.). 
According to the experts (who were asked to provide ratings from 1 to $6 ; 1$ - most important; 6 - less important), social problems in Lithuania are most frequently determined by psychological, economic and social factors; cultural, political and legal factors have less impact (Figure 5).

Kendall's coefficient of concordance (W) (Kendall, 1990) was used to measure agreement between the experts interviewed, where the values of the coefficient are: $\mathrm{W} \rightarrow 0$ - no agreement between raters; $\mathrm{W} \rightarrow 1-$ raters' assessments are similar. The calculated coefficient of concordance suggests that the opinions of the experts on the determinants of social problems are concordant $(\mathrm{W}=0.87)$.

Representatives of social business initiatives assessed the areas of activity where social business have the greatest opportunities or prospects in Lithuania. According to the experts $(\mathrm{W}=0.93)$, the most needed services are the provision of social services and the development of the local community. Labour integration services, economic development and social cohesion, and education and research are slightly less prospective (Figure 6). Cultural activities and ecofriendly consumption services have been rated as the least prospective and necessary areas.

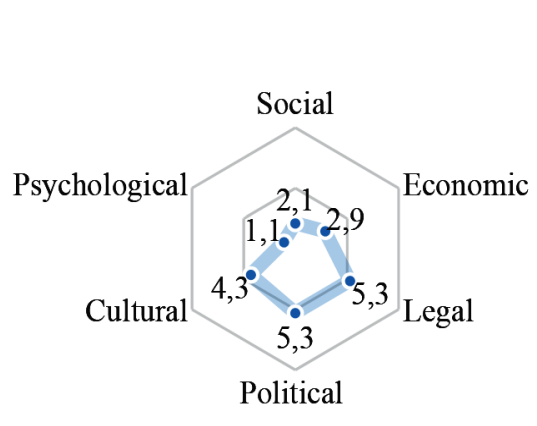

Figure 5. Determinants of social problems in Lithuania (source: compiled by authors)

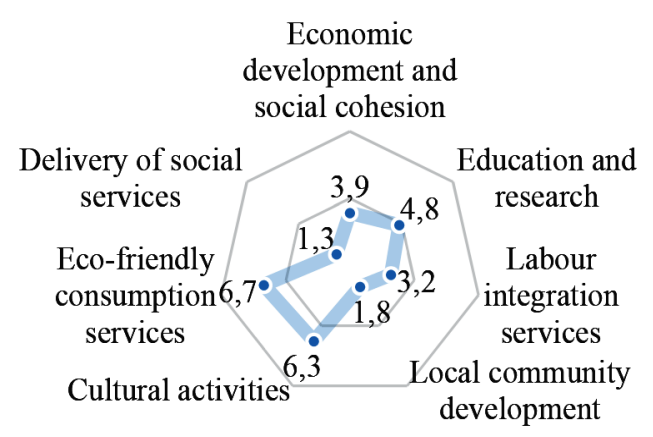

Figure 6. Prospective areas for social business development in Lithuania (source: compiled by authors)

Expert opinions (number of objects $\mathrm{m}>7$, therefore the significance of the concordance coefficient was determined using the $\chi^{2}$ criterion: $\chi^{2}=63.7$; experts are concordant) as to the main barriers hampering the development of social business in Lithuania are rather concordant (Figure 7): development in Lithuania is hampered by: (1) lack of social capital; (2) low interest of entrepreneurs and investors in the social business model; (3) no legal framework regulating social business.

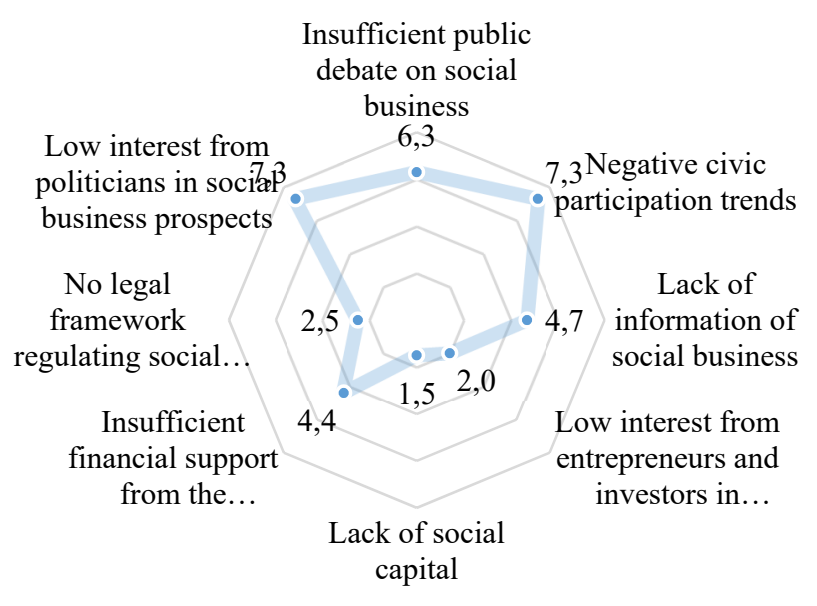

Figure 7. Barriers hampering the development of social business in Lithuania (source: compiled by authors)

Insufficient financial support from the government and local authorities and the lack of information on social business are also hampering the development of social business.

\section{Urgent decisions for the development of social business}

The analysis of the factors and opportunities for boosting social business and of relatively sluggish development pace in Lithuania shows that the question that inevitably arises is what to do. What to do in our country to make the social business model capable of providing social services in an innovative way, contribute more to wealth creation. What measures could be taken to overcome barriers to the development of social business? 
Responsibility for the lack of legal regulation - delaying the adoption of the law on social entrepreneurship development - and inactiveness is not only on the legislature. More activity from associated structures would probably even more accelerate the processes. Clearly regulated opportunities could become an impetus for the greater interest from traditional business and new businesses. Another problem related to the adoption of this law which is still open has to do with a social business whose problem-solving experience should not be destroyed or denied. Therefore, the question remains whether the law on social entrepreneurship development which is currently being drafted will enable the social business to become part of the social business (European Commission, 2012). Another question which is still open is about the political solution for economic entities to acquire the status of a social enterprise: validation of a more flexible (more "American") concept of social business would ensure more rapid development.

Along with the law, opportunities for social advertising would open up: dissemination of values and mission on television, Internet and in public events for investors and entrepreneurs could encourage the development of social businesses, more vigorous search for investors, sponsors or just peers in foreign countries (Maniokas, 2012).

Entrenching the concept of social business in-laws would undoubtedly provide an impulse for the development of social capital, i.e. an impetus for social business to develop faster through social networks. Social capital is traditionally understood as values, networks of communication and collaboration, and results of the collaboration. Bearing in mind the possibilities of this century to disseminate information promoting social values and to instantly share information about problems, solutions and opportunities, this is probably the mere consequence of the first two obstacles: the appropriate legal framework is the guarantor for creative business and a potential business niche for entities searching for business ideas. The legal framework also functions as a security guarantor by providing greater opportunities to organize activities at a lower risk. Finally, the socially effective activity itself usually becomes a factor generating social capital.

\section{Conclusions}

Social business focused on a social mission can take two models of operation - pure and hybrid. The main operating principles of the pure social business model are a clearly defined social business mission, results measured by social impact rather than by generated profits, and reinvestment of all of the profits into further activities ensuring the solution of social problems. The hybrid social business model is characterized by maximizing the created social value through various business strategies, concurrently seeking financial benefits for the shareholders. A flexible concept of social business setting criteria for hybrid social business would enable more enterprises to get engaged in solving social problems and create greater social value. Validating the flexible model (concept) could ensure faster development of social business in the country.

The conducted survey showed that the main social problems in social business development are determined by economic and psychological poverty. Homeless, disabled, unemployed people, disadvantaged families, single elderly people, and single parents with children are the main target groups for social business. Social business, as a social innovation, has been already recognized globally as an important tool to combat poverty, lack of educational opportunities, unemployment and growing social exclusion. Social business are developing in Lithuania, albeit at a slow pace. Most of them are embedded and integrated social business such as non-governmental organizations, charity foundations and social enterprises. In order to boost development, it is necessary to pay more attention to external social business that can be developed by the traditional business sector.

The survey of social business situation and development trends showed that social problems are determined by human values, stereotypes rooted in society, behavioral norms, unemployment, income inequality, accessibility to services, lack of access to higher education, place of residence, discrimination, and social stigma. Social problems are determined by psychological, social and economic factors. Bearing in mind that the origins of any problems are economic, whereas social and psychological problems are the consequences transforming into interoperable factors of greater economic problems, fight against poverty might be identified as the main goal of social business. Therefore, the results of the survey are not surprising: even $52 \%$ of social business in Lithuania have chosen disadvantaged families as their target group, $26 \%$ have chosen people living close to the relative poverty line, $18 \%$ target the unemployed, and only the remaining $4 \%$ provide help and support to single elderly people. The most promising areas for social business are the delivery of social services and the development of local communities. Slightly less promising, but nonetheless necessary are labor integration services, economic development and social cohesion, and education and research. Cultural activities and eco-friendly services are seen as less important areas.

The major obstacles hampering social business: lack of social capital, low interest from entrepreneurs, investors in the social business model, no legal framework regulating social business. However, all those reasons are mutually dependent. The results of the research allow proposing solutions that can serve as catalysts for the breakthrough to pave the way for social business development: validating of a flexible model of social business in legal framework and investments in a social advertising campaign. Validation would make possibilities for enterprises to use support and exemptions. Official statistics would provide preconditions for further research: to evaluate the social and economic efficiency of social business by the cost-benefit analysis method. 


\section{References}

Alter, K. (2007). Social enterprise typology. Retrieved from https://www.globalcube.net/clients/philippson/content/medias/download/SE_typology.pdf

Brooks, A. C. (2008). Social entrepreneurship: a modern approach to social value. Retrieved from https://entrepreneurship.okstate.edu/files/Social_Entrepreneurship_A_Modern_Approach_to_Social_Value_Creation.pdf

Campos, J. L. M., Spear, R., \& Frobel, L. (2012). The social economy in the European Union (No. CESE/contract CES, pp. 18106). Retrieved from https://www.eesc.europa.eu/resources/docs/qe-31-12-784-en-c.pdf

Dees, J. G. (2007). Philanthropy and enterprise: harnessing the power of business and social entrepreneurship for development. Retrieved from https://www.brookings.edu/ /media/events/2007/8/01sustainable\%20development/2007dees.pdf

Dees, J. G., Emerson, J., \& Economy, P. (2001). Enterprising nonprofits: a toolkit for social entrepreneurs. New York.

Department of Trade and Industry. (2002). Social enterprise: a strategy for success. Retrieved from https://www.fafgmbh.de/www/media/socialenterpriseastrategyforsucess.pdf

Dietrich, M., Znotka, M., \& Guthor, H. (2015). Instrumental and noninstrumental factors of social innovation adoption. In Voluntas. International Society for Third-Sector Research and The Johns Hopkins University. Retrieved from https://link.springer.com/article/10.1007/s11266-015-9639-2

European Commission. (2012). Social business initiative. Creating a favourable climate for social enterprises, key stakeholders in the social economy and innovation. Retrieved from https://www.europarl.europa.eu/sides/getDoc.do?pubRef=//EP//TEXT+REPORT+A7-2012-0305+0+DOC+XML+V0//LT

Haber, J. (2016). The business of good: social entrepreneurship and the new bottom line. Irvine, United States: Entrepreneur Press.

Idowu, S. O., Schmidpeter, R., \& Fifka, M. S. (2015). Corporate social responsibility in Europe. United in sustainable diversity. In CSR, Sustainability, Ethics \& Governance. Cham: Springer. https://doi.org/10.1007/978-3-319-13566-3

Jakubavičius, A., Leichteris, E., \& Stumbrytè, G. (2016). Socialinio verslo pletros Lietuvoje galimybiu studija [Feasibility study of social business development in Lithuania]. Lietuvos inovacijų centras, Žinių ekonomikos forumas. Retrieved from https://www.utenosvvg.lt/wp-content/uploads/2016/07/Socialinio_verslo_studija.pdf

Kramer, M. (2005). Measuring innovation: evaluation in the field of social entrepreneurship. Retrieved from https://www.fsg.org/Portals/0/Uploads/Documents/PDF/Measuring_Innovation.pdf?cpgn=WP\%20DL\%20$\% 20$ Measuring\%20Innovation

Lisetchi, M., \& Brancu, L. (2013). The entrepreneurship concept as a subject of social innovation. Retrieved from https://www.researchgate.net/publication/270846629_The_Entrepreneurship_Concept_as_a_Subject_of_Socia 1_Innovation

Maniokas, K. (2012). Socialinio verslo pletros perspektyvos Lietuvoje. Retrieved from file:///C:/Users/User/Downloads/socialinio_\%20verslo_\%20pletros_perspektyvos_\%20Lietuvoje\%20(4).pdf

Melnikas, B., Jakubavičius, A., Leichteris, E., \& Stumbrytė, G. (2017). Socialinis verslas: sistematika ir mechanizmai. Vilnius: Technika.

Murray, R., Caulier-Grice, J., \& Mulgan, G. (2010). The open book of social innovation. London: The Young Foundation. Retrieved from https://www.youngfoundation.org/wp-content/uploads/2012/10/The-Open-Book-of-Social-Innovationg.pdf

National Institute for Social Integration. (2017). Retrieved from https://www.zmogui.lt

Nicholls, A. (2008). Social entrepreneurship: new models of sustainable social change. Oxford: Oxford University Press.

Phills, J. A., Deiglmeier, K., \& Miller, D. T. (2008). Rediscovering social innovation. Stanford Social Innovation Review, 6(4), 3443.

Santos, F. M. (2012). A positive theory of social entrepreneurship. Journal of Business Ethics, 111(3), 335-351. https://doi.org/10.1007/s10551-012-1413-4

Schwab foundation for social entrepreneurship. (2018). Retrieved from https://www.schwabfound.org

Social Enterprise Summit, Report. (2017). Retrieved from https://www.socialinisverslas.lt/wp-content/uploads/2017/06/SOC_EN_17.pdf

Stroh, D. P. (2015). Systems thinking for social change: a practical guide to solving complex problems, avoiding unintended consequences, and achieving lasting results. Chelsea Green Publishing.

Stroputė, N., \& Kairyte, M. (2016a). Kas daro socialinị versla socialiniu verslu? Gerosios užsienio praktikos analizė [What makes social business a social business? Analysis of good foreign practice]. Young Professionals Programme (YPP). Retrieved from https://kurklt.lt/wp-content/uploads/2015/11/U\%C5\%BEsienio-\%C5\%A1ali\%C5\%B3-SV-vystymosi-ir-pl\%C4\%97trosgerosios-praktikos-analiz\%C4\%97_Neringa-ir-Modesta_2016_Kurk-Lietuvai_.pdf

Stroputè, N., \& Kairytė, M. (2016b). Social business guide. Retrieved from https://ukmin.lrv.lt/uploads/ukmin/documents/files/SVV/Socialinio\%20verslo\%20gidas_2016(0525).pdf

Venturi, P., \& Zandonai, F. (2012). Social enterprise in Italy. Plurality of models and contribution to growth Iris. Retrieved from https://www.aiccon.it/wp-content/uploads/2017/01/Social_Innovation_and_Social_Enterprises.pdf

Yunus, M. (2007). Creating a world without poverty. United States: Public Affairs.

Yunus, M. (2010). Building social business. United States: Public Affairs.

Yunus, M. (2017). A world of three zeros: the new economics of zero poverty, zero unemployment, and zero net carbon emissions. Hachette, UK. 